\title{
Occurrence of multipolar mitoses and association with Aurora-A/-B kinases and p53 mutations in aneuploid esophageal carcinoma cells
}

\author{
Christiane D Fichter ${ }^{1}$, Corinna Herz ${ }^{1,3}$, Claudia Münch ${ }^{1}$, Oliver G Opitz ${ }^{2}$, Martin Werner ${ }^{1}$ and Silke Lassmann ${ }^{1 *}$
}

\begin{abstract}
Background: Aurora kinases and loss of p53 function are implicated in the carcinogenesis of aneuploid esophageal cancers. Their association with occurrence of multipolar mitoses in the two main histotypes of aneuploid esophageal squamous cell carcinoma (ESCC) and Barrett's adenocarcinoma (BAC) remains unclear. Here, we investigated the occurrence of multipolar mitoses, Aurora-A/-B gene copy numbers and expression/activation as well as p53 alterations in aneuploid ESCC and BAC cancer cell lines.

Results: A control esophageal epithelial cell line (EPC-hTERT) had normal Aurora-A and -B gene copy numbers and expression, was p53 wild type and displayed bipolar mitoses. In contrast, both ESCC (OE21, Kyse-410) and BAC (OE33, OE19) cell lines were aneuploid and displayed elevated gene copy numbers of Aurora-A (chromosome 20 polysomy: OE21, OE33, OE19; gene amplification: Kyse-410) and Aurora-B (chromosome 17 polysomy: OE21, Kyse410). Aurora-B gene copy numbers were not elevated in OE19 and OE33 cells despite chromosome 17 polysomy. Aurora-A expression and activity (Aurora-A/phosphoT288) was not directly linked to gene copy numbers and was highest in Kyse-410 and OE33 cells. Aurora-B expression and activity (Aurora-B/phosphoT232) was higher in OE21 and Kyse-410 than in OE33 and OE19 cells. The mitotic index was highest in OE21, followed by OE33 > OE19 > Kyse-410 and EPC-hTERT cells. Multipolar mitoses occurred with high frequency in OE33 (13.8 $\pm 4.2 \%)$, followed by OE21 $(7.7 \pm 5.0 \%)$ and Kyse-410 $(6.3 \pm 2.0 \%)$ cells. Single multipolar mitoses occurred in OE19 $(1.0 \pm 1.0 \%)$ cells. Distinct p53 mutations and p53 protein expression patterns were found in all esophageal cancer cell lines, but complete functional p53 inactivation occurred in OE21 and OE33 only.

Conclusions: High Aurora-A expression alone is not associated with overt multipolar mitoses in aneuploid ESCC and BAC cancer cells, as specifically shown here for OE21 and OE33 cells, respectively. Additional p53 loss of function mutations are necessary for this to occur, at least for invasive esophageal cancer cells. Further assessment of Aurora kinases and p53 interactions in cells or tissue specimens derived from non-invasive dysplasia (ESCC) or intestinal metaplasia (BAC) are necessary to disclose a potential causative role of Aurora kinases and p53 for development of aneuploid, invasive esophageal cancers.
\end{abstract}

\section{Background}

Esophageal cancer is one of the leading causes of death from cancers worldwide. The two major histotypes of esophageal cancer are esophageal squamous cell carcinoma (ESCC) and Barrett's adenocarcinoma (BAC) [1,2].

Several specific molecular alterations play crucial roles in the carcinogenesis of ESCC or BAC, with tumor cell aneuploidy and p53 mutations being major hallmarks of

\footnotetext{
* Correspondence: silke.lassmann@uniklinik-freiburg.de

${ }^{1}$ Institute of Pathology, University Medical Center, Freiburg, Germany

Full list of author information is available at the end of the article
}

both ESCC and BAC [3-5]. In fact, aneuploidy is found in $50 \%$ to $70 \%$ of ESCC and is associated with poor prognosis [6,7]. In BAC, similar high rates of aneuploidy are seen for invasive carcinomas $[8,9]$, and aneuploidy is an early event in the metaplasia-dysplasia-adenocarcinoma sequence of BAC. Moreover, p53 is mutated in $35 \%$ to $80 \%$ of ESCC and in about $50 \%$ to $90 \%$ of BAC $[4,10,11]$.

Together with deregulation of mitotic and post-mitotic cell cycle control points, the presence of supernumerary centrosomes has been proposed as one likely 
mechanism for development and/or maintenance of aneuploidy [12]. Supernumerary centrosomes have been detected in several aneuploid human cancers or cell lines derived thereof by evaluation of centrosomal proteins, such as $\gamma$-tubulin, pericentrin or Inhibitor of DNA binding protein 1 (ID1) [13-15]. However, the association of supernumerary centrosomes with multipolar mitoses in aneuploid ESCC and BAC cells has not been studied so far.

The Aurora kinase family of serine/threonine kinases regulates many processes during cell division and is currently discussed as therapeutic target in cancer $[16,17]$. Specifically, Aurora-A is important for centrosome maturation, separation and spindle assembly [16]. Amplification of the Aurora-A locus (AURKA, 20q13.2) and subsequent overexpression of Aurora-A was observed for example in colorectal [18] and pancreatic cancer [19], as well as in ESCCs and BACs [20-26]. Overexpression of Aurora-A has been functionally associated with supernumerary centrosomes and aneuploidy [27-31]. In esophageal cancers, a polymorphism of Aurora-A was associated with increased esophageal cancer risk. This Aurora-A polymorphism showed reduced Aurora-A kinase activity, lack of phosphorylation of its substrate Lats2 and associated genetic instability, at least by ectopic expression of the Aurora-A isoforms in immortalized fibroblasts [32]. Whether or not lack of Lats2 phosphorylation alone and/or other alterations of the Aurora-A isoforms, such as incorrect intracellular localization, are responsible for genomic instability in esophageal cancer cells remained elusive.

In contrast, Aurora-B is involved in kinetochoremicrotubule interactions, chromosome condensation and cytokinesis [16]. Together with INCENP, survivin and borealin, Aurora- $B$ builds the chromosomal passenger complex [33]. The Aurora-B gene $(A U R K B)$ is located in the chromosomal region 17p13.1 [16], which is also frequently altered in ESCCs and BACs [34-37]. Although the role of Aurora-B in human cancer is less clear than for Aurora-A, an association between Aurora$\mathrm{B}$ overexpression and aneuploidy has been reported for some cancer cell lines [16,38]. However, in esophageal cancer the association of Aurora-A and Aurora-B with occurrence of multipolar mitoses in aneuploid ESCC or BAC cells remains elusive so far.

In view of the crucial role of the tumor suppressor p53 for maintenance of genetic stability $[39,40]$ and its frequent mutation in esophageal cancer $[4,10,11]$, it is of interest that also a centrosomal localization and functional involvement in centrosome duplication has been described for p53 [41-43]. Moreover, p53 can be phosphorylated by Aurora-A, leading to MDM2 dependent p53 inactivation and degradation and/or loss of p53 transactivation activity $[44,45]$. Together, (Aurora-A dependent or independent) disruption of p53 function may result in escape of the p53 dependent G1 postmitotic checkpoint [46] and potentially also centrosomal dysfunction.

The aim of the present study was to investigate the occurrence of multipolar mitoses and association with Aurora kinases and p53 mutations in previously established esophageal carcinoma cell lines [47-49] and control esophageal epithelial cells [50-52].

\section{Results}

Ploidy and cell cycle distribution in normal esophageal epithelial cells and esophageal cancer cells

For the present study, a control diploid cell line derived from normal esophageal epithelial cells $[50,51]$ as well as four aneuploid esophageal cancer cell lines with squamous cell (OE21, Kyse-410, hereafter referred to as ESCC) and adenocarcinoma (OE33, OE19, hereafter referred to as "BAC") differentiation and growth patterns $[47-49,52]$, i.e. closely reflecting the morphological features of the two main histotypes of esophageal cancer, were used. All experimental data shown are derived from each three independent experiments.

Ploidy, respective DNA content, as well as cell cycle distribution patterns of all five cell lines was first defined by flow cytometry. This validated diploidy of EPChTERT cells and aneuploidy to different levels in the esophageal cancer cell lines (Figure 1A). To further define chromosome numbers in the aneuploid esophageal cancer cell lines, each 10 metaphase spreads were analyzed and revealed highest chromosome numbers in OE33 (100.2 \pm 4.4$)$, followed by Kyse-410 (89.6 \pm 5.1$)$, OE21 (70.6 \pm 2.5$)$ and OE19 (56.8 \pm 1.8$)$ cells. Analyses of cell cycle distribution (Figure 1B) revealed that ESCC cells (OE21, Kyse-410) showed similarly distributed cell populations in G0/G1-, S- and G2/M-phases (each about $20-30 \%)$. In contrast, OE33 ( 30\%) and markedly OE19 $(\sim 50 \%)$ and EPC-hTERT ( 70\%) cells had a high G0/G1-phase population, with reduced S- and G2/Mphase populations.

\section{Aurora kinases in normal esophageal epithelial cells and esophageal cancer cells}

For Aurora-A (Table 1, Figure 2), fluorescence in situ hybridization (FISH) revealed chromosome 20 polysomy with concomitantly elevated Aurora-A gene copy numbers in OE21, OE33 and OE19 cells and an Aurora-A gene amplification with up to nine Aurora-A gene copies in Kyse- 410 cells. In view of their Aurora-A gene amplification, Kyse-410 cells also showed highest Aurora-A mRNA (qRT-PCR) and high protein (immunoblot) expression. In contrast, OE21, OE33 and OE19 cells exhibited lower Aurora-A mRNA expression, despite chromosome 20 polysomy. Still, high Aurora-A 


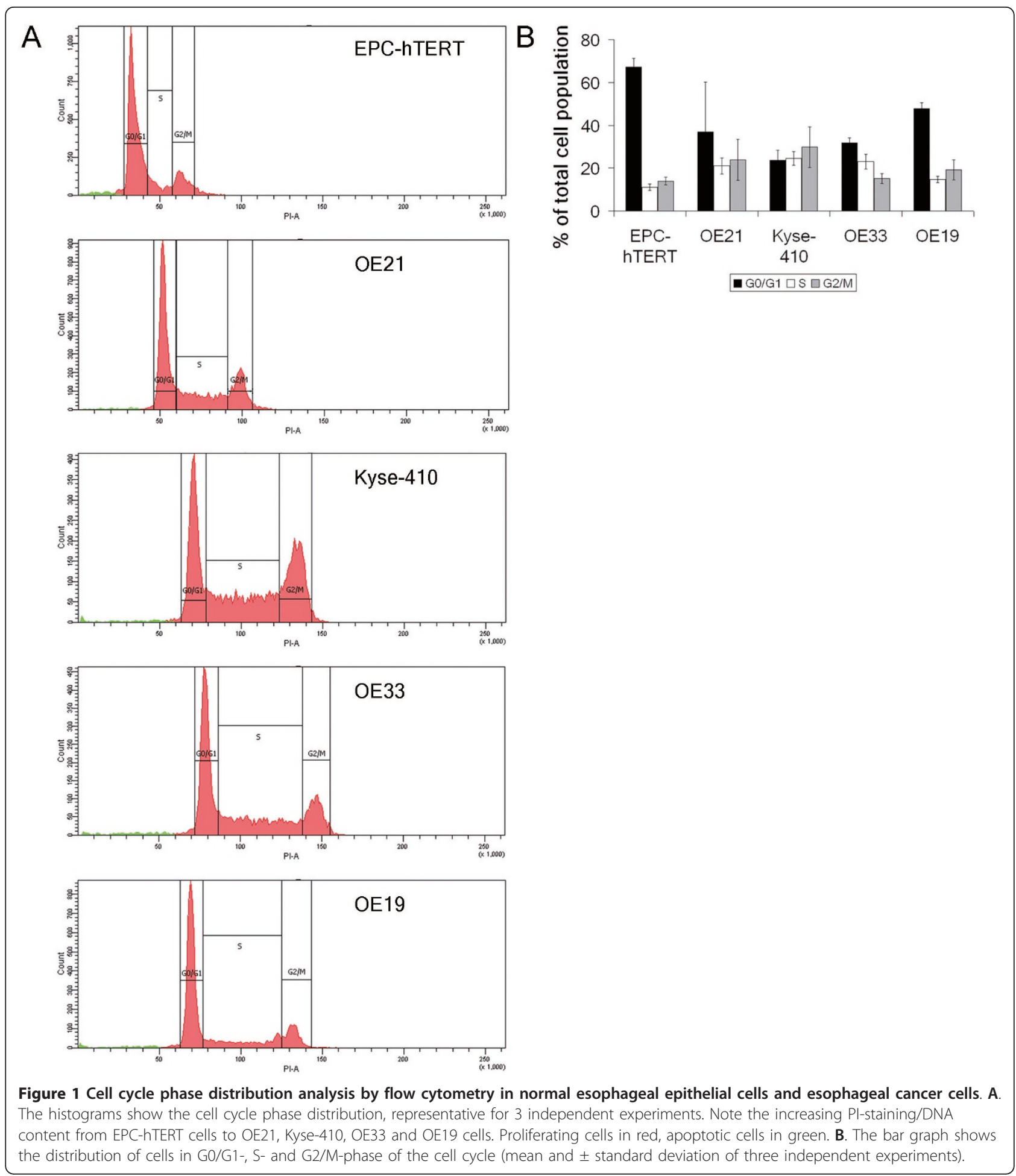

protein expression was seen in OE33, but not OE21 and OE19 cells. Active (phosporylated T288) Aurora-A was hardly detectable in immunoblot analysis, but weak Aurora-A/phosphoT288 levels were seen in OE21, Kyse-410 and OE33 cells. Control EPC-hTERT cells had normal diploid Aurora-A gene copy numbers, lowest Aurora-A
mRNA expression, but detectable strong Aurora-A and weak Aurora-A/phosphoT288 protein levels.

For Aurora-B (Table 1, Figure 3), chromosome 17 polysomy and concomitantly elevated Aurora-B gene copy numbers were observed by FISH in the ESCC cell lines OE21 and Kyse-410. Interestingly, in the BAC cell 
Table 1 Aurora-A and -B gene copy numbers in normal esophageal epithelial and esophageal cancer cell lines

\begin{tabular}{|c|c|c|c|c|c|}
\hline & \multirow[b]{2}{*}{ EPC-hTERT } & \multicolumn{2}{|c|}{ ESCC } & \multicolumn{2}{|c|}{ BAC } \\
\hline & & OE21 & Kyse-410 & OE33 & OE19 \\
\hline \multicolumn{6}{|l|}{ Aurora-A } \\
\hline Aurora-A gene copies & $2.0 \pm 0.2$ & $4.2 \pm 0.5$ & $9.1 \pm 1.2$ & $7.5 \pm 0.9$ & $3.9 \pm 0.3$ \\
\hline Centromere 20 signals & $1.9 \pm 0.3$ & $4.1 \pm 0.7$ & $4.6 \pm 0.9$ & $7.2 \pm 0.9$ & $2.9 \pm 0.4$ \\
\hline Aurora-A/CEP20 ratio & $1.1 \pm 0.3$ & $1.1 \pm 0.3$ & $2.0 \pm 0.4$ & $1.1 \pm 0.1$ & $1.4 \pm 0.2$ \\
\hline \multicolumn{6}{|l|}{ Aurora-B } \\
\hline Aurora-B gene copies & $1.9 \pm 0.4$ & $3.0 \pm 0.1$ & $3.7 \pm 0.8$ & $2.9 \pm 0.7$ & $2.0 \pm 0.2$ \\
\hline Centromere 17 signals & $2.0 \pm 0.2$ & $3.0 \pm 0.1$ & $3.8 \pm 0.7$ & $4.9 \pm 0.9$ & $3.9 \pm 0.4$ \\
\hline Aurora-B/CEP17 ratio & $1.0 \pm 0.2$ & $1.0 \pm 0.0$ & $1.0 \pm 0.1$ & $0.6 \pm 0.2$ & $0.5 \pm 0.1$ \\
\hline
\end{tabular}

The table summarizes results of FISH analyses of control esophageal epithelial cells (EPC-hTERT) and all four esophageal cancer cell lines, with mean and \pm standard deviation of gene specific (Aurora-A, Aurora-B) and centromere (CEP, chromosome enumeration probe) specific FISH signals as well as the amplification status (gene to centromere ratio: Aurora-A to CEP20; Aurora-B to CEP17).

lines OE33 and OE19 elevated chromosome 17 specific signals with lower Aurora-B gene specific signals, resulting in Aurora- $B$ to chromosome 17 ratios below 1, were observed. Accordingly, both ESCC (OE21, Kyse-410) cell lines had slightly higher Aurora-B mRNA and protein expression than the BAC cell lines (OE33, OE19). Active (phosphorylated T232) Aurora-B was apparent in OE21, Kyse-410 and OE33 cells. Control EPC-hTERT cells had normal diploid Aurora-B gene copy numbers, similar Aurora-B mRNA as BAC cell lines, but undetectable Aurora-B protein expression or activity.

The low Aurora-B gene copy numbers and protein expression in the two BAC cell lines were not due to a general phenomenon of entire chromosome 17 alterations, since (other than AURKB at 17p13) HER2 gene copy numbers (17q21) were highly amplified in these two cell lines (Supplementary figure 1).

Thus, Aurora-A and -B gene copy numbers are linked to mRNA expression patterns, but this is not directly translated into altered protein or activity levels. Whilst high Aurora-A and Aurora-B protein levels largely reflect DNA copy numbers as well as cell cycle distribution in some cell lines (OE21, Kyse-410), decoupling of Aurora-A and/or -B gene copy numbers with expression and cell cycle distribution occurs in other cell lines (particularly OE33).

High Aurora-A expression alone is not associated with occurrence of multipolar mitoses in esophageal cancer cells Aurora-A gene amplification and protein overexpression have been linked to the occurrence of supernumerary centrosomes, formation of multipolar mitoses and aneuploidy $[27,30]$. We therefore next examined the occurrence of Aurora-A positive multipolar mitoses in the EPC-hTERT as well as the four esophageal cancer cell lines. For this, three independent experiments were performed by quantitative, Aurora-A specific, indirect immunofluorescence [30] with asynchronized cells, to detect occurrence of mitoses and multipolar mitoses in view of their own cell cycle dynamics (Table 2, Figure 4). Parallel hematoxylin and eosin (HE) staining confirmed the data on mitotic cells morphologically and pericentrin-specific indirect immunofluorescence $[14,30]$ confirmed the presence of Aurora-A associated supernumerary centrosomes.

To specify the previous flow cytometric analyses (Figure 1 ), which only provided data on the total number of G2/M-phase cells, the mitotic index (i.e. only mitotic cells per total cells in \%) was evaluated in indirect immunofluorescence analysis of Aurora-A and nuclear (DAPI) staining. For each cell line at least 100 cells were counted in three independent experiments (total at least 300 cells for each cell line; Table 2A, Figure 4). This revealed the highest mitotic index in OE21 (4.6 $\pm 1.2 \%)$, followed by OE33 (3.4 $\pm 2.25 \%)$, OE19 (3.2 $\pm 1.9 \%)$, Kyse-410 (2.2 $\pm 0.4 \%)$ and EPC-hTERT $(1.0 \pm 0.0 \%)$ cells.

Similarly, the occurrence of multipolar mitoses (i.e. multipolar mitoses per total mitoses in \%) was assessed by quantifying indirect immunofluorescence analysis of Aurora-A and nuclear (DAPI) stainings. For this, in each cell line at least 80 mitoses were counted in three independent experiments (total at least 265 mitoses for each cell line; Table 2B, Figure 4). Aurora-A positive multipolar mitoses were most frequent in OE33 (13.8 \pm $4.2 \%)$ followed by OE21 $(7.7 \pm 5.0 \%)$ and Kyse-410 (6.3 $\pm 2.0 \%)$ cells. OE19 cells $(1.0 \pm 1.0 \%)$ as well as EPChTERT cells $(0.3 \pm 0.6 \%)$, if any, only had single Aurora-A positive multipolar mitoses. Presence of supernumerary centrosomes in these multipolar mitoses was confirmed by pericentrin staining (Figure 4, right panels).

These data suggest that similarly high Aurora-A expression (as seen e.g. for Kyse-410 and OE33 cells) alone is insufficient to induce prominent multipolar mitoses in aneuploid esophageal cancer cells. 


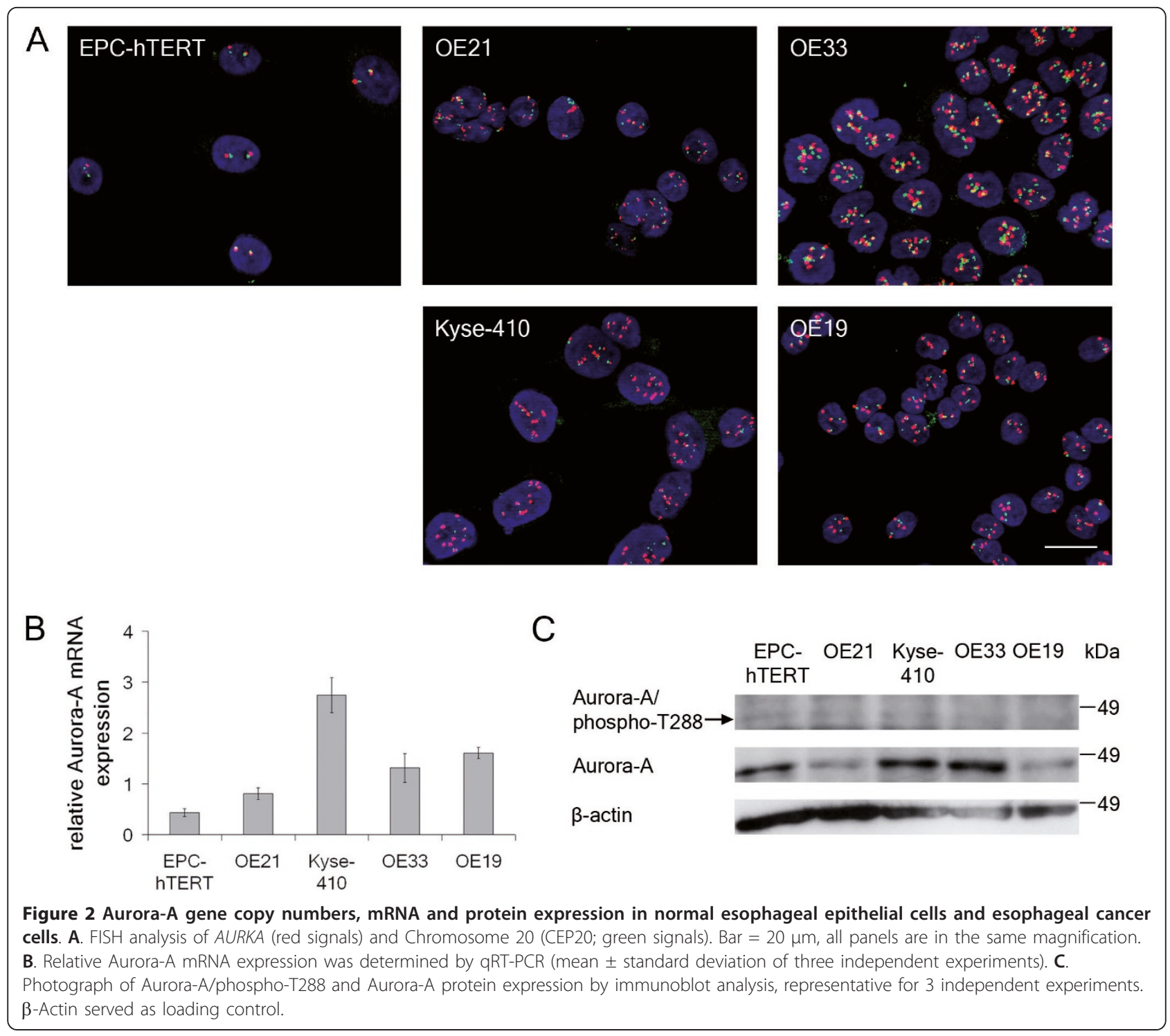

\section{Distinct p53 mutations contribute to multipolar mitoses in esophageal cancer cells}

In view of the role of p53 in post-mitotic cell cycle control, centrosome duplication and Aurora-A interaction [41-45,53] as well as its frequent mutation in esophageal carcinogenesis $[4,10,11]$, we next determined p53 mutation status $[54,55]$, p53 protein expression and intracellular localization [39] in the control EPChTERT cell line and in the four esophageal cancer cell lines (Figure 5).

The control EPC-hTERT cells exhibited a wild type p53 sequence and showed weak p53 protein expression in immunoblot (Figure 5B) and indirect immunofluorescence analysis (Figure $5 \mathrm{C}$ ). This wild type p53 protein was located in the cytoplasm of EPC-hTERT cells.
In contrast, all ESCC and BAC cell lines displayed p53 mutations (Figure 5A): OE21 cells exhibited p53 mutations in exon 4 (c.269C>T, c.270delC, p.S90fs31X), which introduce a stop codon at the N-terminus of the p53 core domain. The p53 protein of OE21 cells lacks almost the entire DNA binding domain, the tetramerization domain and the extreme C-terminus (protein mass of truncated protein is about $14 \mathrm{kDa}$ ). This protein, if at all being expressed, is most likely non-functional since almost all domains are missing, including the Aurora-A interaction sites Serine 215 and 315. Indeed, immunoblot analysis did not detect this largely truncated p53 protein (Figure 5B) and immunofluorescence showed only weak and rather diffusely localized p53 staining in OE21 cells (Figure 5C). 


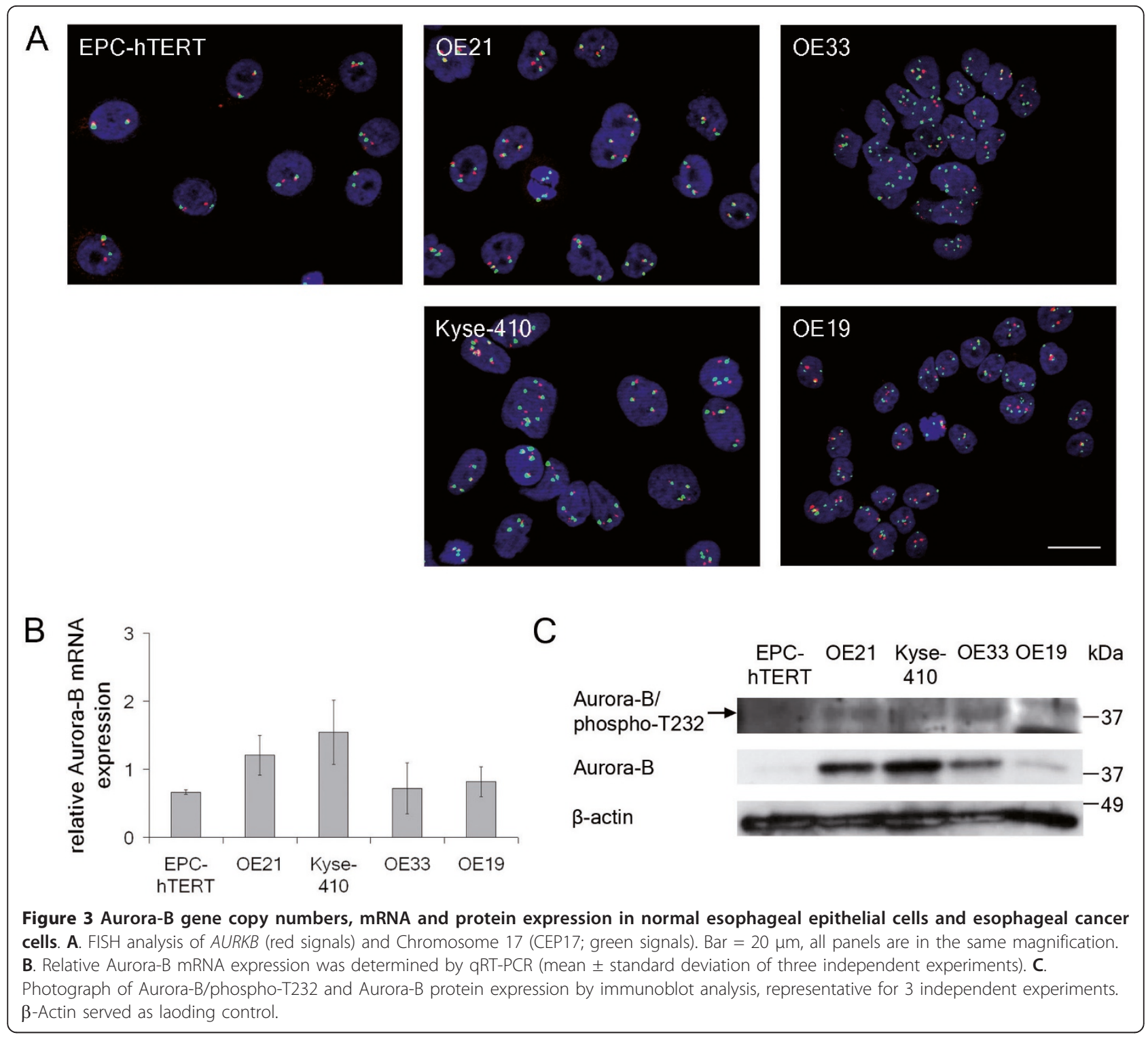

Kyse- 410 cells displayed a point mutation in exon 10 (c.1009C > T, p.R337C) of the tetramerization domain (Figure 5A). This mutation was neither found in the original human cancer, of which this cell line was derived from, nor in the original Kyse-410 cell line [56]. However, it was later reported in Kyse-410 cells [57]. There are conflicting reports about whether this mutated p53 protein forms tetramers, binds DNA, induces apoptosis and transactivates target genes or not. It seems that p53 with this mutation is partially functional depending on the experimental conditions [58-60]. In our case, this mutated p53 protein was clearly detectable in immunoblot analysis (Figure 5B) and displayed a strong nuclear staining in most, but not all Kyse- 410 cells by indirect immunofluorescence (Figure 5C).
OE33 cells had a point mutation in exon 5 (c.404G >A, p.C135Y), which is consistent with previous reports [57] (Figure 5A). This mutation abolishes the p53 transactivation activity as well as growth suppressive activity of the mutated protein and has a dominant negative effect on wild type p53 [61,62]. Accordingly, this mutated p53 protein was still expressed and accumulated in OE33 cell nuclei, although in some cells to a weaker extent (Figure 5B, C).

OE19 cells exhibited a mutation in exon 9 (c.928_930insA, p.N310fs26X), which is in accordance with mutation databases [57]. This mutation is within the flexible linker, which connects the p53 core domain with the tetramerization domain, causes a stop codon within the tetramerization domain (protein mass of 
Table 2 Mitotic index and occurrence of multipolar mitoses in normal esophageal epithelial cells and esophageal cancer cells.
A

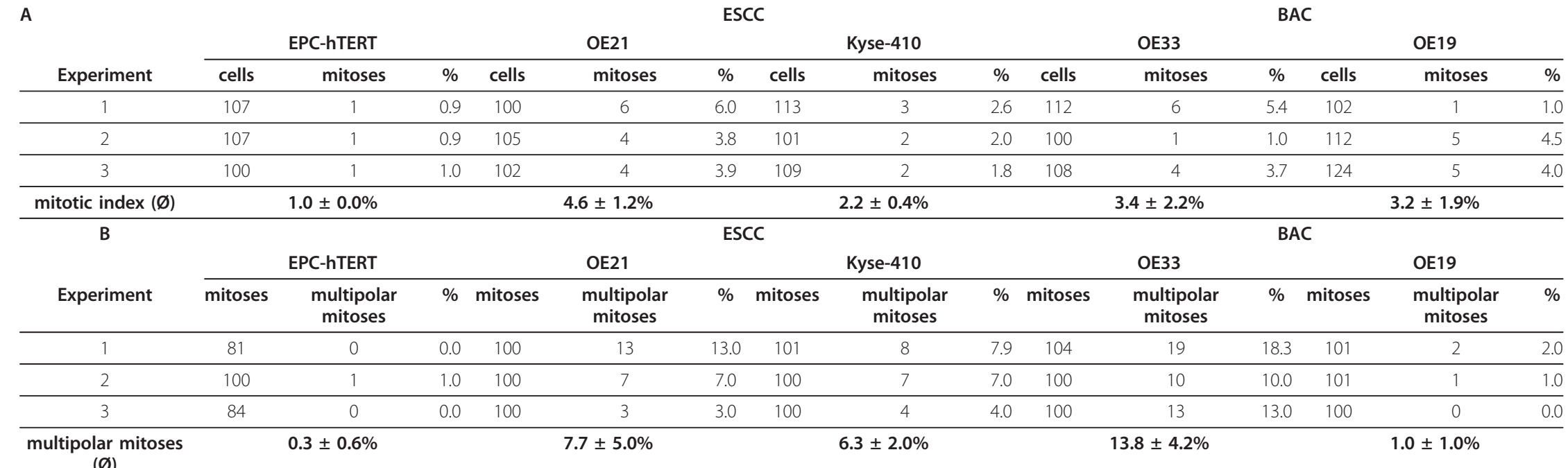

(Ø)

(A) Summary of the evaluation of the mitotic index. In three independent experiments, about 100 cells were counted and the number of mitoses therein was determined after Aurora-A immunofluorescence staining The table also provides mean and \pm standard deviation of the percentage of mitoses. (B) Summary of the evaluation of the index of multipolar mitoses. In three independent experiments, about 100 mitoses were counted and the number of multipolar mitoses therein was determined after Aurora-A immunofluorescence staining. The table also provides mean and \pm standard deviation of the percentage of multipolar mitoses. 


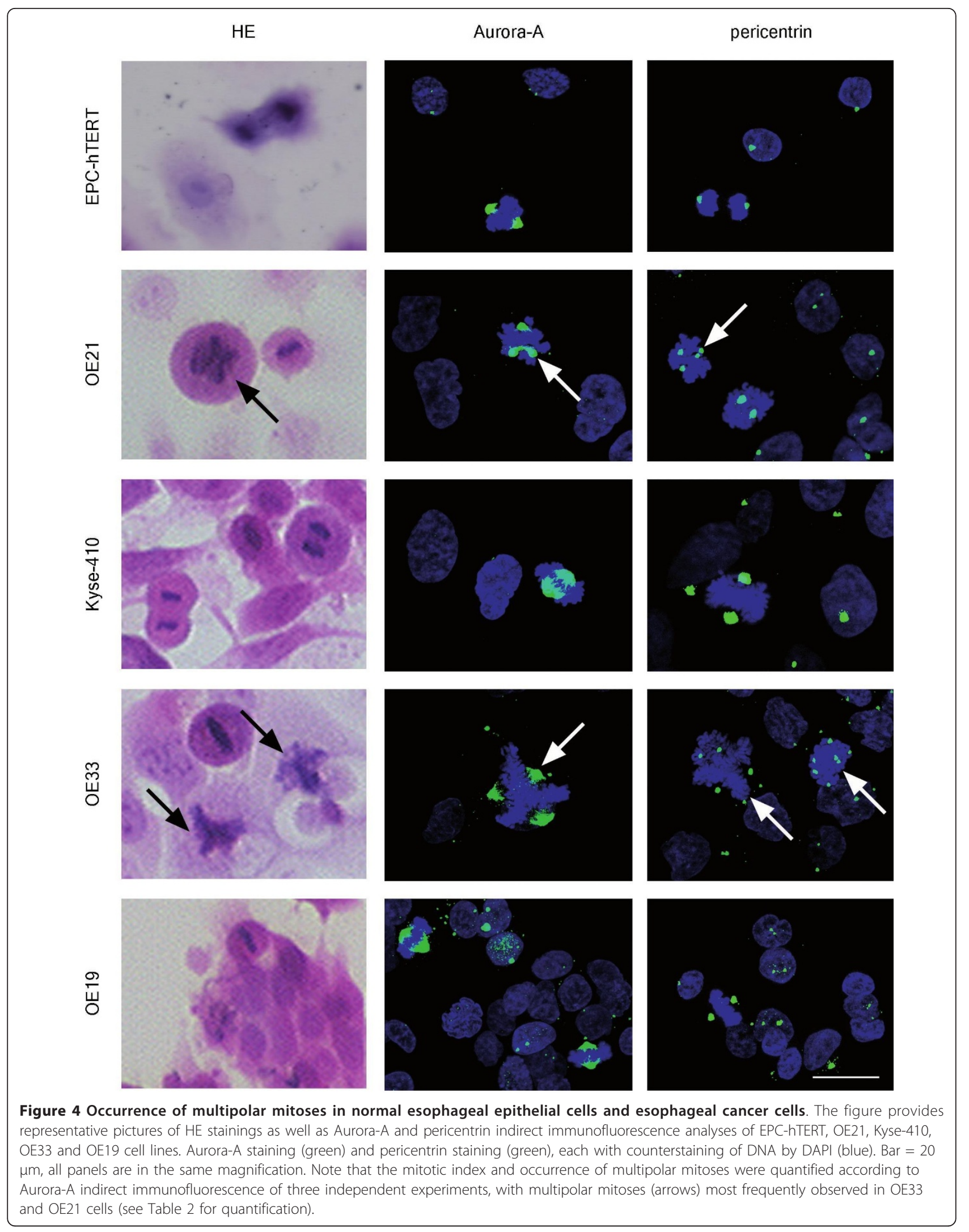




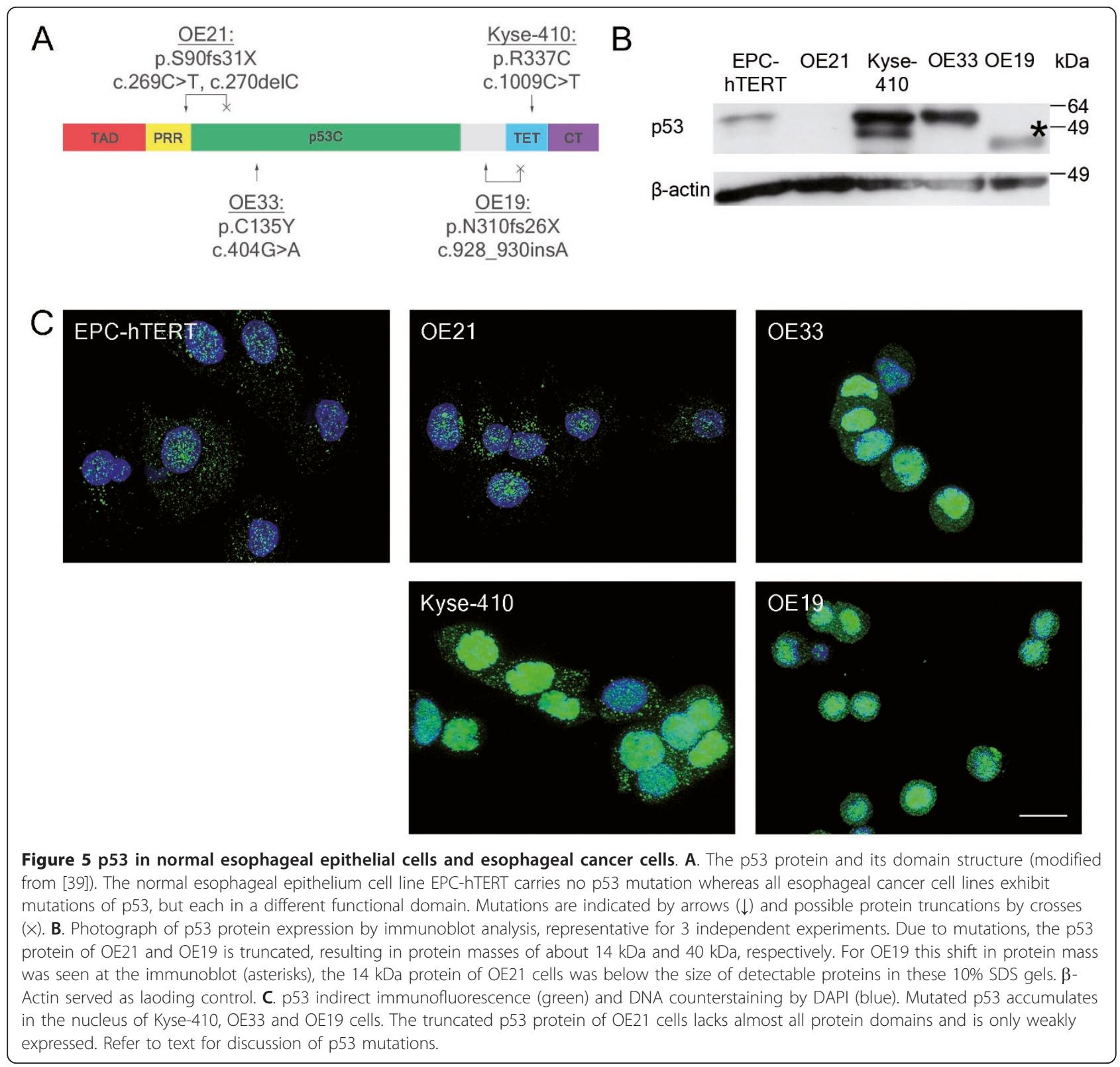

truncated protein is about $40 \mathrm{kDa}$ ) and most likely inactivates p53 oligomerization (Figure 5A). However, the latter is insufficient to fully abolish p53 tumor suppressive function and p53 monomer mutants with retention of transcriptional activity have been described [58]. In OE19 cells, this potentially still functional mutated p53 protein was strongly expressed as truncated protein at $40 \mathrm{kDa}$ in immunoblot analysis (Figure 5B, asterisks) and clearly accumulated in OE19 cell nuclei (Figure 5C).

Thus, loss of function p53 mutations may result in escape of post-mitotic G1 cell cycle control and possibly also centrosomal dysfunction [41-45] in some (OE21, OE33), but not all (Kyse-410, OE19) esophageal cancer cells.

\section{Discussion}

This study addressed Aurora kinases A and B, p53 mutations and occurrence of multipolar mitoses in aneuploid esophageal squamous cell carcinoma (ESCC) and Barrett's adenocarcinoma (BAC) cell lines (for data summary refer to Table 3 ).

Amplification of $20 \mathrm{q} 13$ and/or Aurora-A has been reported to occur frequently in human esophageal carcinomas by extract-based methods, such as (array-based) comparative genomic hybridization [24,34,36,37]. The present study confirms the importance of this chromosomal region in ESCC and $\mathrm{BAC}$, but our precise single cell FISH analyses of each two ESCC and BAC cell lines suggests that high level Aurora-A gene amplification is a 
Table 3 Summary of investigated parameters in normal esophageal epithelial cells and esophageal cancer cell lines.

\begin{tabular}{|c|c|c|c|c|c|}
\hline & \multirow[b]{2}{*}{ EPC-hTERT } & \multicolumn{2}{|l|}{ ESCC } & \multicolumn{2}{|r|}{ BAC } \\
\hline & & OE21 & Kyse-410 & OE33 & OE19 \\
\hline \multicolumn{6}{|l|}{ Aurora-A } \\
\hline Aurora A gene copies & $2.0 \pm 0.2$ & $4.2 \pm 0.5$ & $9.1 \pm 1.2$ & $7.5 \pm 0.9$ & $3.9 \pm 0.3$ \\
\hline Centromere 20 signals & $1.9 \pm 0.3$ & $4.1 \pm 0.7$ & $4.6 \pm 0.9$ & $7.2 \pm 0.9$ & $2.9 \pm 0.4$ \\
\hline Aurora-A mRNA & $0.4 \pm 0.1$ & $0.8 \pm 0.1$ & $2.7 \pm 0.3$ & $1.3 \pm 0.3$ & $1.6 \pm 0.1$ \\
\hline Aurora-A protein & ++ & + & ++++ & +++ & + \\
\hline Aurora-A/phospho T288 & + & + & + & $(+)$ & $(+)$ \\
\hline \multicolumn{6}{|l|}{ Aurora-B } \\
\hline Aurora-B gene copies & $1.9 \pm 0.4$ & $3.0 \pm 0.1$ & $3.6 \pm 0.8$ & $2.9 \pm 0.7$ & $2.0 \pm 0.2$ \\
\hline Centromere 17 signals & $2.0 \pm 0.2$ & $3.0 \pm 0.1$ & $3.8 \pm 0.7$ & $4.9 \pm 0.7$ & $3.9 \pm 0.4$ \\
\hline Aurora A mRNA & $0.7 \pm 0.0$ & $1.2 \pm 0.3$ & $1.5 \pm 0.5$ & $0.7 \pm 0.4$ & $0.8 \pm 0.2$ \\
\hline Aurora-B protein & $(+)$ & +++ & ++++ & ++ & + \\
\hline Aurora-B/phospho T232 & $(+)$ & + & + & + & - \\
\hline \multicolumn{6}{|l|}{ p53 } \\
\hline Mutations & no mutation & c.269C>T, c.270delC, p.S90fs31X & c.1009C>T, p.R337C & c.404G>A, p.C135Y & c.928_930insA, p.N310fs26X \\
\hline p53 protein $(\mathrm{kDa})$ & 53 & $\sim 14$ (truncated) & 53 & 53 & $\sim 40$ (truncated) \\
\hline p53 functionality & + & - & $+/-$ & + & $+/-$ \\
\hline \multicolumn{6}{|l|}{ Mitoses } \\
\hline Mitotic Index (\%) & $1.0 \pm 0.0 \%$ & $4.6 \pm 1.2 \%$ & $2.2 \pm 0.4 \%$ & $3.4 \pm 2.2 \%$ & $3.2 \pm 1.9 \%$ \\
\hline Multipolar mitoses (\%) & $0.3 \pm 0.6 \%$ & $7.7 \pm 5.0 \%$ & $6.3 \pm 2.0 \%$ & $13.8 \pm 4.2 \%$ & $1.0 \pm 1.0 \%$ \\
\hline
\end{tabular}

Quantitative data of each three independent experiments are summarized for FISH and q-RT-PCR (relative mRNA expression) analyses as well as for mitoses and multipolar mitoses (mean and \pm standard deviation). Immunoblot analyses are depicted with minus $(-)$ to increasingly positive $(+$ to ++++$)$ protein expression. Identified p53 mutations and associated effects are listed.

rather rare event in esophageal cancer cells. A clear-cut Aurora-A gene amplification was only seen in Kyse-410 cells, as described before [24], whilst all other investigated cell lines had increased Aurora-A gene copy numbers due to chromosome 20 polysomy. Moreover, elevated Aurora-A gene copy numbers may not necessarily result in elevated Aurora-A mRNA and/or protein expression, as exemplified by our results of OE21 and OE19 cells. Also, Aurora-A gene copy numbers are far from a direct link to activated Aurora-A (phosphorylated at T288) protein levels. Whilst cell cycle dynamics of esophageal cancer cells clearly impact detection levels of Aurora-A expression, additional regulation of Aurora-A expression by transcriptional, for example via epidermal growth factor receptor [63], and posttranslational, for example via the ubiquitin-proteasome pathway [64], mechanisms may further act in individual esophageal cancer cells. Indeed, the clinical relevance of Aurora-A in esophageal cancers has mainly been determined at the expression level $[20,22,23]$.

In contrast to Aurora-A, there was a more close association between Aurora-B gene copy numbers and Aurora-B mRNA and protein expression in the ESCC and BAC cell lines. Both ESCC cell lines (OE21, Kyse-410) had elevated Aurora-B gene copy numbers due to chromosome 17 polysomy and concomitant high Aurora-B expression, but not activation (phosphorylation at T232). Instead, both BAC cell lines (OE33, OE19) displayed lower Aurora-B gene specific signals than chromosome 17 specific signals with concomitantly low Aurora-B mRNA as well as protein expression and activity. In fact, also our previous studies showed broad chromosomal deletions on $17 \mathrm{p}$ close to the Aurora-B locus in up to $40 \%$ of tissue specimens of BACs [36,37], whilst other investigators reported controversial results for chromosome 17p alterations in tissue specimens of ESCC [34,35]. In order to rule out that this is due to a major chromosome 17 alteration, we performed FISH and immunoblot analysis for HER2 (17q21), clearly demonstrating that HER2 is highly amplified in these two BAC cell lines. This suggests that the detected genomic alteration is specific to $17 \mathrm{p}$, respective potentially the Aurora-B gene. The apparently "reduced" Aurora-B gene copy numbers in BAC cells may be due to a partial deletion, loss of the short arm of chromosome 17 or even duplication of centromere 17 alone. It will be of interest for future studies to investigate potentially deregulated chromosome integrity, for example by telomere alterations or breakage-fusion-bridge cycles, during mitosis of BAC cells.

Irrespective of this, the present results allow further insights into the direct association of high Aurora-A 
expression with supernumerary centrosomes and the associated occurrence of multipolar mitoses and aneuploidy described in other model systems $[27,30]$ now also for aneuploid esophageal cancer cells. For example, ectopic overexpression of functional Aurora-A in diploid colorectal cancer cell line [31] or ectopic expression of kinase deficient Aurora-A isoforms, which is unable to phosphorylate its substrate Lats2, in immortalized fibroblasts [32] both resulted in either supernumerary centrosomes, chromosome segregation defects and/or genomic instability.

In fact, we found that high Aurora-A expression in aneuploid ESCC or BAC cells does not determine the occurrence of multipolar mitoses alone: 1) although exhibiting similarly high Aurora-A expression, only OE33 cells, but not Kyse-410 cells were characterized by a high frequency of multipolar mitoses and 2) of the two cell lines with markedly lower Aurora-A expression (OE21, OE19), OE21 cells did in fact show a noticeable frequency of multipolar mitoses, being higher than in strongly Aurora-A expressing Kyse-410 cells.

Thus, other factors are required to sustain cycling of multipolar mitotic esophageal cancer cells in order to allow development and maintenance of individual aneuploid ESCC and BAC cell clones. Since up to $80 \%$ of ESCC and $90 \%$ of BAC display mutations of p53 $[4,10,11]$, this tumor suppressor protein is a very likely contributing factor, particularly in view of its role in G1 cell cycle and DNA damage control, its centrosomal function [39-43] as well as its inactivation and/or degradation upon interaction with Aurora-A [44,45]. Thus, cells with still intact or only partial dysfunctional p53 protein may still have p53 dependent G1 cell cycle control, a scenario that was of interest for the present data, particularly for the ESCC Kyse-410 cells.

In the present study, p53 mutations were found in the four representative esophageal cancer cell lines, but in different domains and therefore with different consequences for protein expression and/or function. None of the p53 mutations detected corresponded to known p53 gain of function mutations [65]. Instead, OE21 cells had p53 mutations (exon 4; c.269C>T, c.270delC, p. S90fs31X), which caused weak expression of a presumably non-functional, largely truncated (about $14 \mathrm{kDa}$ ) p53 protein. Also OE33 cells had a p53 mutation (exon 5; c.404G>A, p.C135Y) resulting in a non-functional, nuclear accumulated p53 protein, lacking transactivation and growth suppressive activity $[61,62]$. In contrast, Kyse-410 cells had a cell culture acquired [56,57] p53 mutation (exon 10; c.1009C>T, p.R337C), resulting in expression and nuclear accumulation of an at least partially functional p53 protein [58-60]. Similarly, the p53 mutation confirmed in OE19 cells (exon 9; c.928_930insA, p.N310fs26X) [57], may cause expression of a truncated (about $40 \mathrm{kDa}$ ), but still partially functional p53 protein with lost oligomerization activity [58]. Thus, esophageal cancer cells with both high Aurora-A expression and p53 loss of function mutations have a high occurrence of multipolar mitoses (e.g. OE33: about $14 \%$ multipolar mitoses). In contrast, esophageal cancer cells with Aurora-A gene amplification and high Aurora-A expression, but an at least partially functional p53 protein have fewer multipolar mitoses (e.g. Kyse-410: about $8 \%$ multipolar mitoses).

In contrast to the esophageal cancer cells, the normal esophageal epithelial cell line EPC-hTERT $[50,51]$ was diploid, had wild type p53 and did show normal Aurora-A and Aurora-B gene copy numbers as well as bipolar mitoses. Still, slightly elevated Aurora-A and p53 protein levels were observed in this cell line. Although no effect of hTERT was seen on p16 and p53 protein levels in the initial description of this cell line [51], others have reported an effect of hTERT-induced downregulation of p16, p21 and up-regulation of Aurora-A in normal esophageal epithelial cells [66], which may explain the detectable Aurora-A protein expression observed in our experiments of EPC-hTERT cells.

\section{Conclusions}

In summary, high Aurora-A expression together with p53 mutations may contribute to aneuploid esophageal cancer cells via supernumerary centrosomes and associated occurrence of multipolar mitoses. This is heterogeneous in single ESCC or BAC cell lines, thereby reflecting the heterogeneity also observed in individual patients with ESCC or BAC [20-25]. The study therefore represents a basis for further translational assessment of Aurora kinases and associated cell cycle control in aneuploid ESCC and BAC cells, particularly also in view of discussions of Aurora kinases as therapeutic targets $[17,67,68]$. Further assessment of Aurora kinases and p53 interactions in cell lines or tissue specimens derived from precursor lesions of dysplasia (for ESCC) or intestinal metaplasia (for BAC) are necessary to disclose a causative role of Aurora kinases and p53 in the development of aneuploid, invasive esophageal cancers.

\section{Methods}

\section{Cell culture}

The study included as control a normal esophageal epithelial cell line (EPC-hTERT cells) [50,51] as well as four esophageal cancer cell lines (OE21, Kyse-410, OE33, OE19). The esophageal cancer cell lines were originally derived from patients with esophageal squamous cell carcinomas (ESCC: OE21, Kyse-410), Barrett's adenocarcinoma (BAC: OE33) or an esophageal junctional adenocarcinoma (OE19) $[47,48]$. Indeed, the specificity of the adenocarcinoma cell lines was recently approved 
[49]. Due to clear adenocarcinoma differentiation and growth patterns, the two cell lines OE33, OE19 are collectively referred to as "BAC" in the present in vitro study, which does not address the carcinogenesis of esophageal carcinomas in view of the intestinal metaplasiadysplasia-carcinoma sequence.

EPC-hTERT cells were cultivated in Keratinocyte-SFM medium (Invitrogen, Karlsruhe, Germany) supplemented with $40 \mu \mathrm{g} / \mathrm{ml}$ bovine pituitary extract (Invitrogen, Karlsruhe, Germany), 1.0 ng/ml EGF (Invitrogen, Karlsruhe, Germany), $100 \mathrm{units} / \mathrm{ml}$ penicillin and $100 \mu \mathrm{g} / \mathrm{ml}$ streptomycin (Invitrogen, Karlsruhe, Germany) at $37^{\circ} \mathrm{C}$ in a $5 \% \mathrm{CO} 2$ atmosphere.

The esophageal cancer cell lines OE21 and Kyse-410 and the BAC cell lines OE33 and OE19 (European Collection of Cell Cultures, Salisbury, UK) were cultivated in RPMI 1640 medium (PAA Laboratories, Pasching, Austria), supplemented with $10 \%(\mathrm{v} / \mathrm{v})$ Fetal Bovine Serum (PAA Laboratories, Pasching, Austria) and $2 \mathrm{mM}$ GIBCO $^{\mathrm{TM}}$ L-Glutamin (Invitrogen, Karlsruhe, Germany) at $37^{\circ} \mathrm{C}$ in a $5 \% \mathrm{CO} 2$ atmosphere.

\section{Hematoxylin and Eosin staining (HE staining)}

Cells grown on coverslips were fixed with $4 \%$ paraformaldehyde (PFA), rinsed with Phosphate buffered saline (PBS: $137 \mathrm{mM} \mathrm{NaCl}, 10 \mathrm{mM} \mathrm{Na} 2 \mathrm{HPO}_{4}, 1.8 \mathrm{mM}$ $\mathrm{KH}_{2} \mathrm{PO}_{4}$; pH 6.8-7) and stained with Hematoxylin (Carl Roth, Karlsruhe, Germany). After removing the hematoxylin solution mains water was added twice. Cells were stained with Eosin Y solution (Carl Roth, Karlsruhe, Germany) and distilled water was added. The coverslips were then immersed in an ascending ethanol series and in xylol.

\section{Cell cycle phase distribution analysis by flow cytometry}

For cell cycle distribution analyses by flow cytometry cells were grown to $50 \%-60 \%$ confluency. The cells in the medium and trypsinized cells were collected and fixed in ice-cold $70 \%(\mathrm{v} / \mathrm{v})$ ethanol. After washing with PBS cells were stained with propidium iodide $(20 \mu \mathrm{g} / \mathrm{ml}$ propidium iodide (Sigma-Aldrich, Steinheim, Germany), $0.1 \%(\mathrm{v} / \mathrm{v})$ Tritron X-100, $0.2 \mathrm{mg} / \mathrm{ml}$ Ribonuclease A (Sigma-Aldrich, Steinheim, Germany) in PBS). Stained cells were analyzed using the LSRII system and DB FACS Diva software (Becton Dickinson, Heidelberg, Germany).

\section{Fluorescence in situ hybridization (FISH)}

Cells were grown on Poly-L-Lysine coated Lab-Tek ${ }^{\circledR} 1$ Well Glass Slides (Thermo Fisher Scientific, Langenselbold, Germany). Cells were washed with PBS, fixed in 3:1 methanol/glacial acetic acid and dehydrated in an ethanol series. AURKA (20q13) \& 20q11 DNA probe (Kreatech Diagnostics, Amsterdam, Netherlands) or
AURKB (17p13)/Alphasatellite 17 specific DNA probe (MP Biomedicals, Illkirch, France) was applied. Co-denaturation was performed for $5 \mathrm{~min}$ at $75^{\circ} \mathrm{C}$ for $A U R K A$ or $80^{\circ} \mathrm{C}$ for $A U R K B$ probes and hybridization for $16-18 \mathrm{~h}$ at $37^{\circ} \mathrm{C}$ in a humidified chamber. After washing in $0.4 \times$ $\mathrm{SSC} / 0.3 \%(\mathrm{v} / \mathrm{v}) \mathrm{NP}-40 \mathrm{pH} 7$ for $2 \mathrm{~min}$ at $73^{\circ} \mathrm{C}$ and in $2 \times$ $\mathrm{SSC} / 0.1 \%(\mathrm{v} / \mathrm{v}) \mathrm{NP}-40 \mathrm{pH}$ 7-7.5 for $1 \mathrm{~min}$ at room temperature (RT), cell nuclei were counterstained with DAPI (Vector Laboratories, Burlingame, USA). Examination was done at a fluorescence microscope (Axioplan2 imaging microscope equipped with a Plan-Apochromat 63×/1.4 oil objective, Carl Zeiss MicroImaging, Göttingen, Germany) with slider module. Image stacks at 0.9 $\mu \mathrm{m}$ intervals were taken of at least three representative fields per cell line. Image stacks were converted into 3D view by AxioVision software (Carl Zeiss MicroImaging, Göttingen, Germany).

For each cell line, the gene (AURKA or AURKB) and chromosome specific signals (centromer enumeration probes/CEP; CEP20 or CEP17) were counted per individual cell nucleus (range of cell nuclei counted: 49-88; a mean of $71.3 \pm 13.1$ cell nuclei per cell line). The mean and standard deviation of the gene (AURKA or AURKB) and chromosome specific signals (CEP20 or CEP17) of counted cell nuclei were calculated for each cell line. The FISH ratio (AURKA to CEP20 and AURKB to CEP17) was calculated for each analyzed cell nucleus and thereof the mean and standard deviation was calculated for each cell line. True gene-specific amplification was considered at a FISH ratio of $>2$. The FISH procedure and quantification has previously been published by us for evaluation of Aurora-A and other gene copy numbers in tissue specimens [18].

\section{Indirect immunofluorescence and evaluation of mitoses}

Cells were grown on coverslips, fixed in $2 \%$ PFA, washed in PBS and permeabilized in $0.5 \%(\mathrm{v} / \mathrm{v})$ Tritron X-100 in PBS. After PBS washing, cells were incubated with blocking buffer (PBS containing $5.0 \%(\mathrm{v} / \mathrm{v})$ normal goat serum and $0.3 \%(\mathrm{v} / \mathrm{v})$ Tritron X-100). Diluted primary antibodies (mouse anti-IAK1/Aurora-A Kinase, 1:100, clone 4, BD Biosciences, Heidelberg, Germany; mouse anti-pericentrin, 1:1000, clone mAbcam 28144, Abcam, Cambridge, UK; mouse anti-p53, 1:50, clone DO-7, DakoCytomation, Hamburg, Germany) were incubated over night at $4{ }^{\circ} \mathrm{C}$, cells were rinsed with PBS and 1:200 diluted fluorescently labelled secondary antibodies (goat-anti-mouse IgG-Alexa488, Invitrogen, Karlsruhe, Germany), were incubated for $1 \mathrm{~h}$ at RT. After washing with PBS and distilled water, cell nuclei were counterstained with DAPI (Vector Laboratories, Burlingame, USA). Note that the p53 antibody used was raised against the $\mathrm{N}$-terminal domain (amino acids 1- 
45), recognizing also mutated and expressed (also truncated) p53 proteins.

Normal bipolar mitoses were defined as mitotic cells with 2 Aurora-A positive centrosomes/spindle poles. Multipolar mitoses were defined as mitotic cells with $>2$ Aurora-A positive centrosomes/spindle poles. In three independent experiments, cells were screened using a x40 objective and a minimum of 100 cells were counted for the mitotic index (mitoses per cells counted in \%; range of total cells counted: 100-124) and up to 100 mitoses per cell line were evaluated for the occurrence of multipolar mitoses (multipolar mitoses per mitoses counted; range of total mitoses counted: 81-104) (Table 2).

\section{Immunoblotting}

Preparation of total protein and determination of protein concentration was performed using the Qproteome ${ }^{\mathrm{TM}}$ Mammalian Protein Prep Kit (Qiagen, Hilden, Germany) and the DC Protein Assay (Bio-Rad, München, Germany) according to the manufacturer's protocols. $10 \mu \mathrm{g}$ of total protein extracts per lane were loaded onto $10 \%$ polyacrylamide gels. Proteins were transferred onto Protran ${ }^{\circledR}$ Nitrocellulose Transfer Membrane (Whatman, Dassel, Germany) by Semi-Dry Blot. After blocking the membrane in $5 \%(\mathrm{~m} / \mathrm{v})$ nonfat dried milk powder in Tris buffered saline with Tween (TBST: $10 \mathrm{mM}$ Tris-Base, $150 \mathrm{mM} \mathrm{NaCl}, 0.1 \%(\mathrm{~m} / \mathrm{v})$ Tween; $\mathrm{pH}$ 7.2-7.4), the primary antibodies diluted in $5 \%(\mathrm{~m} / \mathrm{v})$ nonfat dried milk powder in TBST (mouse anti-IAK1/ Aurora-A Kinase, 1:250, clone 4, BD Biosciences, Heidelberg, Germany; rabbit anti-Aurora-B, 1:5000, clone EP1009Y. Epitomics, Burlingame CA, USA; mouse antip53, 1:1000, clone DO-7, DakoCytomation, Hamburg, Germany; mouse anti- $\beta$-Actin, 1:1000, clone AC-15, Sigma-Aldrich, Steinheim, Germany) or 3\% BSA in TBST (rabbit anti Aurora-A/phospho-T288, 1:1000, clone C39D8, Cell signalling, Danvers MA, USA) or 5\% BSA in TBST (rabbit anti-Aurora-B/phospho-T232, 1:500, Abcam, Cambridge, UK) were incubated. After HRP conjugated secondary antibody (1:25000, Dianova, Hamburg, Germany) incubation, the membrane was incubated with ECL reagents (GE Healthcare, Freiburg i. Br., Germany) and exposed to autoradiography films. Note that the p53 antibody used was raised against the $\mathrm{N}$-terminal domain (amino acids 1-45), recognizing also mutated and expressed (also truncated) p53 proteins.

\section{p53 mutation analysis}

Genomic DNA was isolated using the QIAamp ${ }^{\circledR}$ DNA Micro Kit (Qiagen, Hilden, Germany) according to the manufacturer's instruction. Amplification of p53 exons 2-11 was performed using primers and protocols slightly modified from previous studies $[54,55]$. PCR was carried out in a $25 \mu \mathrm{l}$ reaction mixture containing $1 \times$ PCR Buffer, 1.5-2.5 mM MgCl2, $12 \mathrm{ng} / \mu \mathrm{l}$ gDNA, 0.4 mM dNTP Mix, $0.4 \mu \mathrm{M}$ forward and reverse primers and $1.25 \mathrm{U}$ Taq DNA polymerase. The PCR was performed with the following conditions: $94^{\circ} \mathrm{C}$ for $4 \mathrm{~min}, 40$ cycles consisting of $94^{\circ} \mathrm{C}$ for $30 \mathrm{sec}, 53-65^{\circ} \mathrm{C}$ for $30 \mathrm{sec}$ and $72^{\circ} \mathrm{C}$ for $30 \mathrm{sec}$, followed by $72^{\circ} \mathrm{C}$ for $7 \mathrm{~min}$. PCR products were purified using the QIAquick ${ }^{\circledR}$ PCR Purification Kit (Qiagen, Hilden, Germany) according to the manufacturer's protocol. Sequencing was performed using BigDye $^{\mathbb{B}}$ Terminator v1.1 Cycle Sequencing Kit (Applied Biosystems, Darmstadt, Germany) according to the manufacturer's instruction. The reactions were performed in $20 \mu \mathrm{l}$ reaction mixture consisting of 3-5 ng PCR product, $0.16 \mu \mathrm{M}$ forward or reverse primers, $20 \%(\mathrm{v} / \mathrm{v})$ BigDye $^{\circledR}$ Ready Reaction Mix and $1 \times$ Big Dye ${ }^{\circledR}$ Sequencing Buffer. A positive control with a $20 \mu \mathrm{l}$ reaction mixture containing $5 \%(\mathrm{v} / \mathrm{v}) \mathrm{pGEM}^{\mathbb{B}}-3 \mathrm{Zf}(+)$ doublestranded DNA control Template, 5\% (v/v) -21 M13 Control Primer (forward), 20\% (v/v) BigDye ${ }^{\circledR}$ Ready Reaction Mix and $1 \times$ Big Dye ${ }^{\circledR}$ Sequencing Buffer was included. The PCR was performed with the following conditions: $96^{\circ} \mathrm{C}$ for $1 \mathrm{~min}, 24$ cycles consisting of $96^{\circ} \mathrm{C}$ for $10 \mathrm{sec}, 50^{\circ} \mathrm{C}$ for $5 \mathrm{sec}$ and $60^{\circ} \mathrm{C}$ for $4 \mathrm{~min}$. DNA was precipitated with ethanol containing $5 \mathrm{mM}$ EDTA and $120 \mathrm{mM}$ sodium acetate, dissolved in formamide and denatured for $5 \mathrm{~min}$ at $95^{\circ} \mathrm{C}$. Capillary electrophoresis was performed using the ABI PRISM ${ }^{\mathrm{TM}} 310$ Genetic Analyzer (Applied Biosystems, Darmstadt, Germany). The Sequencing Analysis Software V 5.2 (Applied Biosystems, Darmstadt, Germany) was used to analyze the collected electropherogram traces and sequencing information. The p53 sequence of the GenBank database with accession number NC_000017.9|NC_000017: c7531642-7512445 was used as reference.

\section{RNA isolation and CDNA synthesis}

Total RNA isolation was performed using the RNeasy ${ }^{\circledR}$ Mini Kit (Qiagen, Hilden, Germany) according to the manufacturer's instruction. For cDNA synthesis, a $9 \mu \mathrm{l}$ reaction mixture containing $200 \mathrm{ng}$ total RNA, $1 \mu \mathrm{l}$ yeast RNA (10 ng/ $\mu \mathrm{l})$ and $2 \mu \mathrm{l}$ Hexanucleotide Mix (10x, Roche Diagnostics, Mannheim, Germany) was incubated for $2 \mathrm{~min}$ at $70^{\circ} \mathrm{C}$ and $10 \mathrm{~min}$ at RT. A second $11 \mu \mathrm{l}$ reaction mixture containing $4 \mu \mathrm{l}$ First Strand Buffer ( $5 \times$, Invitrogen, Karlsruhe, Germany), $2 \mu$ DTT $(0.1 \mathrm{M}), 1 \mu \mathrm{l}$ dNTP Mix $(10 \mathrm{mM})$ and $1 \mu \mathrm{l}$ M-MLV RT (200U/ $\mu$ l, Invitrogen, Karlsruhe, Germany), was added and incubated for $1 \mathrm{~h}$ at $37^{\circ} \mathrm{C}$. The M-MLV RT was inactivated for $5 \mathrm{~min}$ at $95^{\circ} \mathrm{C}$. For reverse transcription of Universal Human Reference RNA (uRNA) (Stratagene, Heidelberg, Germany) [69], the calibrator of qRTPCR, 300 ng RNA was employed in an appropriate volume. 


\section{Quantitative reverse transcription PCR (qRT-PCR)}

qRT-PCR was performed using established protocols for Aurora-A and TBP [18]. Following Aurora-B primers and probes were used (sequence 5'-3'): Aurora-B-forward (900 nM): CAT GAG CCG CTC CAA TGT C, Aurora-B-reverse (50 nM): CCC AAT CTC AAA GTC ATC AAT TGT, Aurora-B-probe (150 nM): 6-FAMACA CCC GAC ATC TTA ACG CGG CA-TAMRA. The comparative $\mathrm{Ct}$ method was used to calculate Aurora-A/-B mRNA levels. The amount of the target gene is normalized to the endogenous housekeeping gene TATA box binding protein (TBP) and these relative fold differences are compared between the experimental and the uRNA calibrator sample $[69,70]$.

\section{Additional material}

\section{Additional file 1: Supplementary Figure S1: HER2 gene copy} numbers in esophageal cancer cells. FISH analysis of HER2 (red signals) and Chromosome 17 (CEP17; green signals). All panels are in the same magnification. Note HER2 gene amplification in OE33 and OE19 cells and chromosome 17 polysomy in all cell lines.

\section{Abbreviations}

BAC: Barrett's adenocarcinoma; CEP: centromere enumeration probe; ESCC: Esophageal squamous cell carcinoma; FISH: Fluorescence in situ hybridization; HE: Hematoxylin and Eosin staining; INCENP: Inner centromere protein; MDM2: Murine double minute-2; M-MLV RT: Moloney Murine Leukemia Virus Reverse Transcriptase; qRT-PCR: Quantitative reverse transcription PCR; TBP: TATA box binding protein; URNA: Universal Human Reference RNA

\section{Acknowledgements and Funding}

The authors thank Mrs. Anja Schöpflin for technical assistance and Prof. Dr. med. Nikolaus Freudenberg for cytological expertise as well as PD Dr. Gisela Keller, Institute of Pathology, TU Munich for discussion of p53 primer details. The authors also greatly acknowledge the support of the Mushett Family Foundation, Chester, NJ, US (grant to SL, MW). This work was part of the diploma thesis in "molecular medicine" of Mrs. Christiane D. Fichter. The study was in parts funded by the Deutsche Forschungsgemeinschaft (DFG CRC850 TP-C5 to SL, MW).

\section{Author details \\ ${ }^{1}$ Institute of Pathology, University Medical Center, Freiburg, Germany. ${ }^{2}$ Tumorzentrum Ludwig Heilmeyer - Comprehensive Cancer Center, University Medical Center, Freiburg, Germany. ${ }^{3}$ Dept. of Environmental Health Sciences, University Medical Center Freiburg, Germany.}

\section{Authors' contributions}

CDF carried out the experimental work, analysed and interpreted data, prepared figures and tables, drafted and revised the manuscript. CH assisted in qRT-PCR and p53 mutation analyses, and interpreted data. CM participated in FISH analysis and interpreted data. OGO interpreted data, approved manuscript.

MW supervised study, interpreted data and approved manuscript. SL designed and supervised the study, analyzed and interpreted data, wrote, revised and approved the manuscript.

\section{Authors' information}

None

Received: 3 November 2010 Accepted: 6 April 2011 Published: 6 April 2011
References

1. Werner M, Flejou JF, Hainaut P, Höfler H, Lambert R, Keller G, Stein HJ: Adenocarcinoma of the oesophagus. In World Health Organization Classification of Tumours Pathology and Genetics of Tumours of the Digestive System. Edited by: Hamilton SR, Aalton LA, Kleihues P, Sobin LH. Lyon: IARC Press; 2000:20-26.

2. Gabbert HE, Shimoda T, Hainaut P, Nakamura Y, Field JK, Inoue H: Squamous cell carcinoma of the oesophagus. In World Health Organization Classification of Tumours Pathology and Genetics of Tumours of the Digestive System. Edited by: Hamilton SR, Aalton LA, Kleihues P, Sobin LH. Lyon: IARC Press; 2000:11-19.

3. Lehrbach DM, Nita ME, Cecconello I: Molecular aspects of esophageal squamous cell carcinoma carcinogenesis. Arq Gastroenterol 2003, 40(4):256-261.

4. Zhang HY, Spechler SJ, Souza RF: Esophageal adenocarcinoma arising in Barrett esophagus. Cancer letters 2009, 275(2):170-177.

5. Souza RF: The molecular basis of carcinogenesis in Barrett's esophagus. $J$ Gastrointest Surg 14(6):937-940.

6. Blant SA, Ballini JP, Caron CT, Fontolliet C, Monnier P, Laurini NR: Evolution of DNA ploidy during squamous cell carcinogenesis in the esophagus. Dis Esophagus 2001, 14(3-4):178-184.

7. Minu AR, Endo M, Sunagawa M: Role of DNA ploidy patterns in esophageal squamous cell carcinoma. An ultraviolet microspectrophotometric study. Cancer 1994, 74(2):578-585.

8. Fang M, Lew E, Klein M, Sebo T, Su Y, Goyal R: DNA abnormalities as marker of risk for progression of Barrett's esophagus to adenocarcinoma: image cytometric DNA analysis in formalin-fixed tissues. Am J Gastroenterol 2004, 99(10):1887-1894.

9. Yu C, Zhang X, Huang Q, Klein M, Goyal RK: High-fidelity DNA histograms in neoplastic progression in Barrett's esophagus. Lab Invest 2007, 87(5):466-472.

10. Kuwano H, Kato H, Miyazaki T, Fukuchi M, Masuda N, Nakajima M, Fukai $Y$, Sohda M, Kimura H, Faried A: Genetic alterations in esophageal cancer. Surg Today 2005, 35(1):7-18.

11. Montesano R, Hollstein M, Hainaut P: Genetic alterations in esophageal cancer and their relevance to etiology and pathogenesis: a review. Int $J$ Cancer 1996, 69(3):225-235.

12. Kops GJ, Weaver BA, Cleveland DW: On the road to cancer: aneuploidy and the mitotic checkpoint. Nat Rev Cancer 2005, 5(10):773-785.

13. Kayser G, Gerlach U, Walch A, Nitschke R, Haxelmans S, Kayser K, Hopt U, Werner M, Lassmann S: Numerical and structural centrosome aberrations are an early and stable event in the adenoma-carcinoma sequence of colorectal carcinomas. Virchows Arch 2005, 447(1):61-65.

14. Pihan GA, Purohit A, Wallace J, Knecht H, Woda B, Quesenberry P, Doxsey SJ: Centrosome defects and genetic instability in malignant tumors. Cancer research 1998, 58(17):3974-3985.

15. Manthey C, Mern DS, Gutmann A, Zielinski AJ, Herz C, Lassmann S, Hasskarl J: Elevated endogenous expression of the dominant negative basic helix-loop-helix protein ID1 correlates with significant centrosome abnormalities in human tumor cells. BMC Cell Biol 2010, 11:2.

16. Vader G, Lens SM: The Aurora kinase family in cell division and cancer. Biochim Biophys Acta 2008, 1786(1):60-72.

17. Dar AA, Goff LW, Majid S, Berlin J, El-Rifai W: Aurora kinase inhibitorsrising stars in cancer therapeutics? Mol Cancer Ther 2010, 9(2):268-78, Epub 2010 Feb 22010.

18. Lassmann S, Danciu M, Muller M, Weis R, Makowiec F, Schulte-Monting J, Hopt UT, Werner M: Aurora A is differentially expressed and regulated in chromosomal and microsatellite instable sporadic colorectal cancers. Mod Pathol 2009, 22(10):1385-1397.

19. Li D, Zhu J, Firozi PF, Abbruzzese JL, Evans DB, Cleary K, Friess H, Sen S: Overexpression of oncogenic STK15/BTAK/Aurora A kinase in human pancreatic cancer. Clin Cancer Res 2003, 9(3):991-997.

20. Agnese V, Cabibi D, Calcara D, Terrasi M, Pantuso G, Fiorentino E, Intrivici C, Colucci G, Aragona F, Gebbia N, et al: Aurora-A overexpression as an early marker of reflux-related columnar mucosa and Barrett's oesophagus. Ann Oncol 2007, 18(Suppl 6):vi110-115.

21. Wang XX, Liu R, Jin SQ, Fan FY, Zhan QM: Overexpression of Aurora-A kinase promotes tumor cell proliferation and inhibits apoptosis in esophageal squamous cell carcinoma cell line. Cell Res 2006, 16(4):356-366. 
22. Tanaka E, Hashimoto $Y$, Ito T, Okumura T, Kan T, Watanabe G, Imamura M, Inazawa J, Shimada Y: The clinical significance of Aurora-A/STK15/BTAK expression in human esophageal squamous cell carcinoma. Clin Cancer Res 2005, 11(5):1827-1834.

23. Tong $T$, Zhong $Y$, Kong J, Dong $L$, Song Y, Fu M, Liu Z, Wang M, Guo L, Lu S, et al: Overexpression of Aurora-A contributes to malignant development of human esophageal squamous cell carcinoma. Clin Cancer Res 2004, 10(21):7304-7310.

24. Yang SB, Zhou XB, Zhu HX, Quan LP, Bai JF, He J, Gao YN, Cheng SJ, Xu NZ: Amplification and overexpression of Aurora-A in esophageal squamous cell carcinoma. Oncol Rep 2007, 17(5):1083-1088.

25. Dar AA, Zaika A, Piazuelo MB, Correa P, Koyama T, Belkhiri A, Washington K, Castells A, Pera M, El-Rifai W: Frequent overexpression of Aurora Kinase A in upper gastrointestinal adenocarcinomas correlates with potent antiapoptotic functions. Cancer 2008, 112(8):1688-98.

26. Rugge M, Fassan M, Zaninotto G, Pizzi M, Giacomelli L, Battaglia G, Rizzetto C, Parente P, Ancona E: Aurora kinase A in Barrett's carcinogenesis. Hum Pathol 41(10):1380-1386.

27. Meraldi $P$, Honda R, Nigg EA: Aurora-A overexpression reveals tetraploidization as a major route to centrosome amplification in $\mathrm{p53}-/$ cells. Embo J 2002, 21(4):483-492

28. Nigg EA: Centrosome aberrations: cause or consequence of cancer progression? Nat Rev Cancer 2002, 2(11):815-825.

29. Holland AJ, Cleveland DW: Boveri revisited: chromosomal instability, aneuploidy and tumorigenesis. Nat Rev Mol Cell Biol 2009, 10(7):478-487.

30. Zhou H, Kuang J, Zhong L, Kuo WL, Gray JW, Sahin A, Brinkley BR, Sen S: Tumour amplified kinase STK15/BTAK induces centrosome amplification, aneuploidy and transformation. Nat Genet 1998, 20(2):189-193.

31. Lentini L, Amato A, Schillaci T, Di Leonardo A: Simultaneous Aurora-A/ STK15 overexpression and centrosome amplification induce chromosomal instability in tumour cells with a MIN phenotype. BMC cancer 2007, 7:212.

32. Kimura MT, Mori T, Conroy J, Nowak NJ, Satomi S, Tamai K, Nagase H: Two functional coding single nucleotide polymorphisms in STK15 (Aurora-A) coordinately increase esophageal cancer risk. Cancer research 2005, 65(9):3548-3554

33. Ruchaud S, Carmena M, Earnshaw WC: Chromosomal passengers: conducting cell division. Nat Rev Mol Cell Biol 2007, 8(10):798-812.

34. Carneiro A, Isinger A, Karlsson A, Johansson J, Jonsson G, Bendahl PO, Falkenback D, Halvarsson B, Nilbert M: Prognostic impact of array-based genomic profiles in esophageal squamous cell cancer. BMC cancer 2008, 8:98.

35. Yen CC, Chen YJ, Chen JT, Hsia JY, Chen PM, Liu JH, Fan FS, Chiou TJ, Wang WS, Lin CH: Comparative genomic hybridization of esophageal squamous cell carcinoma: correlations between chromosomal aberrations and disease progression/prognosis. Cancer 2001, 92(11):2769-2777.

36. Albrecht B, Hausmann M, Zitzelsberger $H$, Stein $H$, Siewert JR, Hopt U, Langer R, Hofler H, Werner M, Walch A: Array-based comparative genomic hybridization for the detection of DNA sequence copy number changes in Barrett's adenocarcinoma. J Pathol 2004, 203(3):780-788.

37. Wiech T, Nikolopoulos E, Weis R, Langer R, Bartholome K, Timmer J, Walch AK, Hofler H, Werner M: Genome-wide analysis of genetic alterations in Barrett's adenocarcinoma using single nucleotide polymorphism arrays. Lab Invest 2009, 89(4):385-397.

38. Nguyen HG, Makitalo M, Yang D, Chinnappan D, St Hilaire C, Ravid K: Deregulated Aurora- $B$ induced tetraploidy promotes tumorigenesis Faseb J 2009, 23(8):2741-2748.

39. Joerger AC, Fersht AR: Structural biology of the tumor suppressor p53. Annu Rev Biochem 2008, 77:557-582.

40. Vousden KH, Lu X: Live or let die: the cell's response to p53. Nat Rev Cancer 2002, 2(8):594-604.

41. Kawamura K, Izumi H, Ma Z, Ikeda R, Moriyama M, Tanaka T, Nojima T, Levin LS, Fujikawa-Yamamoto K, Suzuki K, et al: Induction of centrosome amplification and chromosome instability in human bladder cancer cells by $\mathrm{p} 53$ mutation and cyclin E overexpression. Cancer research 2004, 64(14):4800-4809.

42. Shinmura K, Bennett RA, Tarapore P, Fukasawa K: Direct evidence for the role of centrosomally localized p53 in the regulation of centrosome duplication. Oncogene 2007, 26(20):2939-2944.

43. Tarapore $P$, Tokuyama $Y$, Horn HF, Fukasawa K: Difference in the centrosome duplication regulatory activity among p53 'hot spot' mutants: potential role of Ser 315 phosphorylation-dependent centrosome binding of p53. Oncogene 2001, 20(47):6851-6863.

44. Katayama H, Sasai K, Kawai H, Yuan ZM, Bondaruk J, Suzuki F, Fujii S, Arlinghaus RB, Czerniak BA, Sen S: Phosphorylation by aurora kinase A induces Mdm2-mediated destabilization and inhibition of p53. Nat Genet 2004, 36(1):55-62.

45. Liu Q, Kaneko S, Yang L, Feldman RI, Nicosia SV, Chen J, Cheng JQ: AuroraA abrogation of p53 DNA binding and transactivation activity by phosphorylation of serine 215. The Journal of biological chemistry 2004, 279(50):52175-52182

46. Kojima K, Konopleva M, Tsao T, Nakakuma H, Andreeff M: Concomitant inhibition of Mdm2-p53 interaction and Aurora kinases activates the p53-dependent postmitotic checkpoints and synergistically induces p53mediated mitochondrial apoptosis along with reduced endoreduplication in acute myelogenous leukemia. Blood 2008, 112(7):2886-2895.

47. Rockett JC, Larkin K, Darnton SJ, Morris AG, Matthews HR: Five newly established oesophageal carcinoma cell lines: phenotypic and immunological characterization. Br J Cancer 1997, 75(2):258-263.

48. Shimada $Y$, Imamura M, Wagata T, Yamaguchi N, Tobe T: Characterization of 21 newly established esophageal cancer cell lines. Cancer 1992, 69(2):277-284.

49. Boonstra JJ, van Marion R, Beer DG, Lin L, Chaves P, Ribeiro C, Pereira AD, Roque L, Darnton SJ, Altorki NK, et al: Verification and unmasking of widely used human esophageal adenocarcinoma cell lines. J Natl Cancer Inst 2010, 102(4):271-4, Epub 2010 Jan 14.

50. Andl CD, Mizushima T, Nakagawa H, Oyama K, Harada H, Chruma K, Herlyn M, Rustgi AK: Epidermal growth factor receptor mediates increased cell proliferation, migration, and aggregation in esophageal keratinocytes in vitro and in vivo. The Journal of biological chemistry 2003, 278(3):1824-1830.

51. Harada H, Nakagawa H, Oyama K, Takaoka M, Andl CD, Jacobmeier B, von Werder A, Enders GH, Opitz OG, Rustgi AK: Telomerase induces immortalization of human esophageal keratinocytes without p16INK4a inactivation. Mol Cancer Res 2003, 1(10):729-738.

52. Underwood TJ, Derouet M, White MJ, Noble F, Moutasim K, Smith E, Drew P, Thomas GJ, Primrose JN, Blaydes JP: A comparison of primary oesophageal squamous epithelial cells with HET-1A in organotypic culture. Biol Cell

53. Giet $R$, Petretti $C$, Prigent $C$ : Aurora kinases, aneuploidy and cancer, a coincidence or a real link? Trends Cell Biol 2005, 15(5):241-250.

54. Keller G, Hartmann A, Mueller J, Hofler H: Denaturing high pressure liquid chromatography (DHPLC) for the analysis of somatic p53 mutations. Lab Invest 2001, 81(12):1735-1737.

55. Ott K, Vogelsang H, Mueller J, Becker K, Muller M, Fink U, Siewert JR, Hofler H, Keller G: Chromosomal instability rather than p53 mutation is associated with response to neoadjuvant cisplatin-based chemotherapy in gastric carcinoma. Clin Cancer Res 2003, 9(6):2307-2315.

56. Tanaka H, Shibagaki I, Shimada Y, Wagata T, Imamura M, Ishizaki K: Characterization of p53 gene mutations in esophageal squamous cell carcinoma cell lines: increased frequency and different spectrum of mutations from primary tumors. Int J Cancer 1996, 65(3):372-376.

57. The IARC TP53 Mutation Database. [http://www-p53.iarc.fr/].

58. Kawaguchi T, Kato S, Otsuka K, Watanabe G, Kumabe T, Tominaga T, Yoshimoto T, Ishioka C: The relationship among p53 oligomer formation, structure and transcriptional activity using a comprehensive missense mutation library. Oncogene 2005, 24(46):6976-6981.

59. Lomax ME, Barnes DM, Hupp TR, Picksley SM, Camplejohn RS Characterization of p53 oligomerization domain mutations isolated from Li-Fraumeni and Li-Fraumeni like family members. Oncogene 1998, 17(5):643-649.

60. Rollenhagen C, Chene P: Characterization of p53 mutants identified in human tumors with a missense mutation in the tetramerization domain. Int J Cancer 1998, 78(3):372-376.

61. Dearth LR, Qian H, Wang T, Baroni TE, Zeng J, Chen SW, Yi SY, Brachmann RK: Inactive full-length p53 mutants lacking dominant wildtype p53 inhibition highlight loss of heterozygosity as an important aspect of p53 status in human cancers. Carcinogenesis 2007, 28(2):289-298.

62. Ichwan SJ, Yamada S, Sumrejkanchanakij P, Ibrahim-Auerkari E, Eto K, Ikeda MA: Defect in serine 46 phosphorylation of p53 contributes to 
acquisition of $\mathrm{p} 53$ resistance in oral squamous cell carcinoma cells. Oncogene 2006, 25(8):1216-1224.

63. Hung LY, Tseng JT, Lee YC, Xia W, Wang YN, Wu ML, Chuang YH, Lai CH, Chang WC: Nuclear epidermal growth factor receptor (EGFR) interacts with signal transducer and activator of transcription 5 (STAT5) in activating Aurora-A gene expression. Nucleic Acids Res 2008, 36(13):4337-4351.

64. Taguchi S, Honda K, Sugiura K, Yamaguchi A, Furukawa K, Urano T: Degradation of human Aurora-A protein kinase is mediated by $\mathrm{hCdh} 1$. FEBS Lett 2002, 519(1-3):59-65.

65. van Oijen MG, Slootweg PJ: Gain-of-function mutations in the tumor suppressor gene p53. Clin Cancer Res 2000, 6(6):2138-45.

66. Zhang H, Jin Y, Chen X, Jin C, Law S, Tsao SW, Kwong YL: Papillomavirus type $16 \mathrm{E} 6 / \mathrm{E} 7$ and human telomerase reverse transcriptase in esophageal cell immortalization and early transformation. Cancer letters 2007, 245(1-2):184-194.

67. Tanaka E, Hashimoto Y, Ito T, Kondo K, Higashiyama M, Tsunoda S, Ortiz C, Sakai Y, Inazawa J, Shimada Y: The suppression of aurora-A/STK15/BTAK expression enhances chemosensitivity to docetaxel in human esophageal squamous cell carcinoma. Clin Cancer Res 2007, 13(4):1331-1340

68. Wang X, Dong L, Xie J, Tong T, Zhan Q: Stable knockdown of Aurora-A by vector-based RNA interference in human esophageal squamous cell carcinoma cell line inhibits tumor cell proliferation, invasion and enhances apoptosis. Cancer Biol Ther 2009, 8(19):1852-9, Epub.

69. Novoradovskaya N, Whitfield ML, Basehore LS, Novoradovsky A, Pesich R, Usary J, Karaca M, Wong WK, Aprelikova O, Fero M, et al: Universal Reference RNA as a standard for microarray experiments. BMC Genomics 2004, 5(1):20.

70. Livak KJ, Schmittgen TD: Analysis of relative gene expression data using real-time quantitative PCR and the 2(-Delta Delta $C(T))$ Method. Methods 2001, 25(4):402-408.

doi:10.1186/1471-2121-12-13

Cite this article as: Fichter et al.: Occurrence of multipolar mitoses and association with Aurora-A/-B kinases and p53 mutations in aneuploid esophageal carcinoma cells. BMC Cell Biology 2011 12:13.

\section{Submit your next manuscript to BioMed Central} and take full advantage of:

- Convenient online submission

- Thorough peer review

- No space constraints or color figure charges

- Immediate publication on acceptance

- Inclusion in PubMed, CAS, Scopus and Google Scholar

- Research which is freely available for redistribution

Submit your manuscript at www.biomedcentral.com/submit
Biomed Central 